\title{
O CONCÍLIO, O PAPADO E O TEMPO: OU ALGUMAS CONSIDERAÇÕES CRÍTICAS SOBRE A INSTITUCIONALIZAÇÃO DO PAPADO MEDIEVAL (1050-1270)
}

\author{
The Papal Council, the Papacy and Time: or some
} critical considerations on the institutionalization of the medieval papacy (1050-1270)

Leandro Duarte Rust*

\begin{abstract}
RESUMO
Este artigo tem por objetivo expor algumas reflexões críticas sobre o processo de institucionalização do papado medieval entre os séculos XI e XIII. Para isso tomaremos como foco de análise a legislação produzida pelo IV Concílio de Latrão (1215), abordando a representação de tempo aí encontrada como objeto de estudo das dimensões e alcances históricos do aparato institucional então produzido pela monarquia pontifícia.
\end{abstract}

Palavras-chave: História Insititucional; Tempo; Papado Medieval.

\begin{abstract}
This article has for objective to display some critical reflections on the process of institutionalization of the medieval papacy one between centuries XI and XIII. For this we will take as focus of analysis the legislation produced for the IV Council of Lateran (1215), approaching the representation of time found there as object of study of the dimensions and you reach descriptions of the institucional apparatus then produced by the pontifical monarchy.
\end{abstract}

Key-words: Insititucional History; Time; Medieval Papacy.

* Doutorando em História pela Universidade Federal Fluminense. 


\section{Prelúdio}

"Desejo veementemente comer esta páscoa convosco antes de sofrer, quero dizer, antes de morrer". ${ }^{1}$ Quando o papa Inocêncio III assim principiou seu pomposo sermão, seu apelo mal podia ser ouvido em meio ao amontoado de vozes que fervilhavam ao longo da igreja de São João de Latrão.

Era dia de São Martinho, 11 de novembro de 1215.

No interior das cinco naves que davam forma a imensa e antiqüíssima basílica romana, uma multidão se acotovelava, e a algazarra por ela instaurada fazia com que o som daquelas palavras, solenemente pronunciadas, morresse aos poucos a cada metro.

Toda esta agitação surgira drasticamente, em instantes, transformando o interior santuário de São João de Latrão. Haja vista que pela manhã, pouco antes do início do sermão pontifício, a serenidade e a paz imperavam no íntimo do templo constantiniano até então reservado para que apenas quatorze cardeais e um punhado de arcebispos assistissem à liturgia celebrada pelo papa. Após a realização das litanias e a leitura do Evangelho, bispos e abades foram chamados a ocupar seus lugares próximos ao sumo pontífice. Foi quando as portas do santuário foram abertas. Rapidamente o baixo clero e o povo invadiram-no, apoderando-se de todo seu interior. Deste modo, as restritas celebrações cederam lugar a uma sessão pública que era planejada e aguardada há dois anos pela Cúria romana. ${ }^{2} \mathrm{Se}$ nos deixarmos guiar pelo relato da Chronica Sancti Petri Efordensis Moderna, veríamos que além da curiosidade despertada pela presença daquela "copiosa multidão de membros do clero", ${ }^{3}$ a massa de fiéis devia ter sido atraída por toda a ornamentação que dignificava ainda mais aquela bela

1 INOCÊNCIO III. Sermão de Abertura do IV Concílio de Latrão. In: MANSI, Joannes (ed.). Sacrorum Conciliorum Nova et Amplissima Collectio. Graz: Akademische Druck, 1961: v. XXII, col. 0968D. (Nos referiremos a esta coletânea de fontes medievais impressas por "MANSI")

2 INOCENCIO III. Epístola XXX. In: MIGNE, Jean-Paul (Ed.). Patrologiae Latina. Paris: Garnier Fratres, 1889-1890, v. 216, col. 0823D. (Nos referiremos a esta coletânea de fontes medievais impressas por "PL").

3 CHRONICAS. PETRI EFORDENSIS MODERNA. In: PERTZ, Georgius Heinricus (Ed.). Monumenta Germaniae Historica. Scriptorum. Leipzig: Unverãnderter Neudruck, 1925, tomo XXX, p. 384. (Nos referiremos a esta coletânea de fontes medievais impressas por "MGH. SS"). 
basílica para ser o palco do concílio cristão planejado como o maior de que se tinham notícias há séculos.

Apesar da igreja de São João de Latrão ser, nesta época, o cenário costumeiro da reunião de grandes públicos, como acontecia durante as liturgias papais da semana santa, nenhuma destas celebrações teria sido comparável à daquele dia de são Martinho. Os Annales Veronenses possivelmente exageram ao apontar a presença de "cerca de quinhentos bispos, mil abades e outros incontáveis clérigos", ${ }^{4}$ já o Chronicon Montis Sereni indica uma cifra mais exata de " 412 bispos, entre os quais dois eram patriarcas [...]. Primazes e metropolitanos foram 71, abades e priores mais de oitocentos". ${ }^{5}$ Aos clérigos somaram-se embaixadores de diversos reinos do Ocidente, e a estes dezenas de fiéis. A basílica tornou-se apinhada. Sobejou. Fervilhou. Transbordou. Assim, o resultado desta aglomeração não tardou a revelar-se trágico: tão logo as ruidosas portas de bronze do santuário foram abertas, este se mostrou sofrivelmente pequeno para tantos espectadores, obrigando aquelas centenas de pessoas a se empurrarem violentamente, lançando-se uns contra os outros, ao chão e de encontro às paredes. No interior desta turba, derrubado, pisoteado e asfixiado, morreu o bispo Mateus de Amalfi. ${ }^{6}$

Eis o cenário comumente descrito por cronistas e historiadores como a abertura do concílio geral convocado por Inocêncio III em abril de 1213, o qual a posteridade nomeou "IV Concílio de Latrão", o maior de todos concílios medievais, um verdadeiro "monumento jurídico" e síntese privilegiada da organização institucional arquitetada pelo papado dos séculos XI e XII.

4 ANNALES VERONENSES. In: MGH. SS: tomo XIX, p. 6.

5 CHRONICON MONTIS SERENI. In: MGH. SS: tomo XXIII, p.186.

6 Dados apresentados por: BOLTON, Brenda. A Reforma na Idade Média. Lisboa: Edições 70, 1983, p. 126; FLICHE, Agustín et al. La Cristiandad Romana. Valência: Edicep, 1976, p. 203; FOREVILLE, Raimunda. Lateranense IV. Vitoria: Eset, 1972, p. 55; GARCIA-VILLOSLADA, Ricardo. Historia de La Iglesia Católica: Edad Media (800-1303). Madrid: Editorial Católica, 197, p.490-491 VAUCHEZ, André et al. Apogée de la Papauté et Expansion de la Chrétienté. Paris, Desclée-Fayard, 1998. p. 545-550; METZ, Rene. Historia de los Concilios. Barcelona: Oikos, 1971, p. 42-43; SAYERS, Jane. Innocent III: leader of Europe 1198-1216. Nova York: Longman Publishing, 1994, p. 98. 


\section{1. "GOVERNAR É TAREFA SEM FIM..."}

Contudo, toda esta desordem não teria impedido o prosseguimento da sessão pública. Após entoar o hino Veni Creator Spiritus e admoestar a assembléia por meio da coleta Actiones nostras, o sumo pontífice deu início a sua homilia citando um fragmento do Evangelho de Lucas: "Desejo veementemente...". Devidamente entronizado e rodeado pelos cardeais, Inocêncio III prosseguia:

Em hebraico o termo páscoa vem de fase, quer dizer passagem [...]. É, pois, uma tripla páscoa a que desejo celebrar convosco: corporal, espiritual e eterna. Corporal ou o trânsito de um lugar a outro para a libertação da desafortunada Jerusalém; espiritual ou o trânsito de um estado a outro para a reforma da Igreja universal; eterna ou o trânsito desta vida a outra para alcançar a glória celeste. ${ }^{7}$

Para o estudioso do medievo este emprego do termo "páscoa" pode ser considerado como muito mais do que um lampejo da espiritualidade acalentada pelo papa ou pelo topo da Igreja romana.

Desde o primeiro século da era cristã, a páscoa é considerada o núcleo espiritual do cristianismo: "o culto da igreja nasceu da páscoa e para celebrar a páscoa". ${ }^{8}$ Esta celebração é um chamamento sublime, para que todos os fiéis integrem uma imensa comunhão, para que testemunhem coletivamente a nova aliança concluída entre os céus e a humanidade. É a ocasião em que toma forma a representação do momento em que o Deus feito carne subjugou a morte e reabriu aos homens os horizontes da salvação após oferecer-se para redimi-los de sua natureza fraca e corrupta, estado deplorável a que foram sentenciados pela falha de Adão. Todavia, esta celebração que torna a eternidade mais próxima é também uma aguda advertência: a recompensa do descanso ao lado do Cristo não é fortuita. A

7 INOCÊNCIO III. Sermão de Abertura do IV Concílio de Latrão. In: MANSI: v. XXII, col. 0969E.

8 SARTORE, Domenico; TRIACCA, Achille. Dicionário de Liturgia. São Paulo: Paulinas, 1992, p. 58. 
páscoa conduz os cristãos a reavaliarem suas trajetórias individuais, a empreenderem escolhas. Muito mais que um brilho de beatitude momentânea, a celebração pascal é uma conclamação ao agir: que o corpo dos fiéis zele pela retidão de suas condutas, que cultive a mansidão da alma ao purgar as faltas cometidas, que levante defesas contra as investidas diárias de sua índole pecaminosa... Com a páscoa os cristãos deparam-se com uma tarefa crucial: tomar parte desta vasta empresa que é ordenar o mundo terrestre para alcançar a Jerusalém celeste.

Contudo, como celebração de um transitus, de uma passagem, de uma sucessão, a páscoa é também o centro gravitacional da representação cristã do tempo. A ressurreição do Cristo destruiu o tempo cíclico do pecado e da morte e inaugurou um tempo linear e salvacionista. Ela é o termo e a meta de toda a história. Nela o passado encontra sua realização e o futuro é antecipado até a consumação do último dia. A Idade Média retomará incessantemente esta caracterização, tornando o tempo indissociável de Deus, seu motor inicial, sua razão criadora e sua lógica essencial. ${ }^{9} \mathrm{O}$ tempo será, então, prisioneiro de uma leitura ritual que culminava nos ritos pascais: o calendário litúrgico. Anunciação, Advento, Natal, Epifania, Quaresma, Semana Santa... Recortes de um ciclo anual que descrevia a vida e os atos do Cristo e organizava o ritmo da existência dos homens. A marcha dos anos, contínua e irreversível, era definida a partir de seu episódio apoteótico: a ressurreição do Deus feito carne. A páscoa é o evento síntese da concepção cristã do tempo, a chave para a compreensão dos significados e sentidos atribuídos ao devir temporal no seio do cristianismo. ${ }^{10}$

Quando Inocêncio III designou por pascha a sessão pública iniciada de forma conturbada naquele dia de são Martinho do décimo oitavo ano de seu pontificado, ele forneceu a nós, estudiosos do passado, uma rica caracterização do alcance histórico do IV Concílio de Latrão. Pois, se por um lado nos deparamos com uma comunhão de cristãos, convocados para a imensa tarefa de tomar por guia a exemplaridade celeste, para reavaliar a organização do corpo eclesial e para agir sobre toda a cristandade para que

9 BLANC, Mafalda Faria. Metafísica do tempo. Lisboa: Instituto Piaget, 1999, p. 125-139; PATTARO, Germano. A concepção cristã do tempo. In: UNESCO (Org.). As culturas e o tempo. Petrópolis: Vozes; São Paulo: Edusp, 1975, p. 201-202.

10 BIGNOTTO, Newton. O círculo e a linha. In: NOVAES, Adauto (Org.). Tempo e história. São Paulo: Cia das Letras, 1992, p. 180. 
o "templo do Senhor seja restaurado [...] e assim se celebre o trânsito ou a páscoa neste concílio solene"; ${ }^{11}$ por outro lado o Lateranense IV é, como a páscoa, a plenitude de uma singular imagem atribuída ao devir, de uma representação do tempo. Um registro síntese de uma temporalidade construída paulatinamente desde meados do século XI e que florescia nas medidas conciliares da Santa Sé desde o ano de 1179, ocasião do III Concílio de Latrão. ${ }^{12}$ E é exatamente esta segunda faceta da "páscoa" celebrada no Lateranense IV a que nos dedicaremos a seguir.

Observemos, primeiramente, a transcrição de algumas medidas aprovadas pelo concílio para a reorganização da hierarquia eclesiástica, a começar pelo cânone IV:

Os metropolitanos deverão celebrar todos os anos com seus sufragâneos, concílios provinciais para refletir no temor a Deus e com todo interesse acerca da correção dos abusos e da reforma dos costumes, principalmente no clero. [...] As medidas adotadas deverão ser observadas; serão publicadas nos sínodos diocesanos que deverão celebrar-se a cada ano em todas as dioceses. ${ }^{13}$ (grifo nosso).

No cânone XI foram os monges os contemplados com uma imposição semelhante: "Em cada reino ou província se celebrará a cada três anos, permanecendo a salvo o direito dos bispos, um capítulo geral dos abades e dos priores sem abade, que até este momento não se vinha celebrando". ${ }^{14}$ (grifo nosso).

Não eram apenas prelados e cenobitas que preocupavam os padres conciliares, mas também as igrejas sem clérigos, como indica o cânone XVII:

11 INOCÊNCIO III. Sermão de Abertura do IV Concílio de Latrão. In: MANSI: v. XXII, col.

0969D.

12 RUST, Leandro Duarte. O papado e o tempo: um estudo comparativo sobre a representação do tempo e o exercício do poder pontifício nos cânones lateranenses (1123 a 1215). 231p. Dissertação (Mestrado em História Comparada) - Instituto de Filosofia e Ciências Sociais/UFRJ, Rio de Janeiro, 2005.

13 Cânone XII. In: HEFELE, Charles; LECLERQ, Henry. Histoire des Conciles. Paris: Letouzey et Ané Editeurs, 1913: tomo V, p. 1342. (Nos referiremos a esta coletânea de fontes conciliares por "HEFELE-LECLERQ").

14 Cânone XII. In: HEFELE-LECLERQ: tomo V, p. 1342. 
Estabelecemos que a vacância de uma igreja catedral ou regular não deverá exceder um período de três meses. Transcorrido este tempo e não existindo impedimento legítimo algum, si não houver celebrado a eleição, aqueles a quem esta corresponde serão privados do direito para levá-la a cabo, a qual passará ao superior imediato. ${ }^{15}$ (grifo nosso).

Os cânones supracitados têm em comum, além do objetivo de reformar a hierarquia eclesiástica, o fato de conterem referenciais temporais explícitos. E todos dispõem destes referenciais de uma mesma e singular maneira: os recortes cronológicos apresentados - os períodos de "um ano", "três anos" e de "três meses" - são os marcos de quando ocorreria uma reedição, uma repetição constante das medidas decretadas pelo concílio. A realização de assembléias clericais provinciais e diocesanas deveria ocorrer a cada ano, por todos os anos, incessantemente: não havia a previsão de um fim. O mesmo se daria com a celebração dos capítulos gerais monásticos, porém sob uma periodicidade de três anos. Já o direito de promover eleições em igrejas vacantes vigoraria por um período limitado de três meses; contudo, até quando este prazo seria o critério de legitimação de uma eleição canônica para uma igreja vacante? Em outras palavras, chegaria o momento em que a validade desta norma canônica teria fim? Em que este prazo de três meses não seria mais o limite da legitimidade de um direito de eleição canônica? Ora, é exatamente por em momento algum levar em conta qualquer questionamento como este, que as atas de 1215 fornecem-nos uma resposta: o prazo deveria ser implementado e respeitado toda vez que uma igreja se tornasse vacante, portanto, vigoraria indeterminadamente ao longo da história, continuamente, sem término previsto.

O cumprimento das proposições contidas nestas constituições não podia ser esporádico ou acidental, não poderia ocorrer eventualmente, caso contrário, não haveria ação clerical organizada, constante e eficaz. O corpo eclesial não dependia que um evento extraordinário surgisse para levar a cabo estas medidas, como se a realização de um sínodo não passasse de uma reação a ocorrências incomuns. A hierarquia eclesiástica romana atrelava-se ao curso duradouro do tempo, fazendo com que suas ações se asse- 
melhassem cada vez mais à marcha temporal: sucessivas, contínuas e ininterruptas.

As tarefas com que se deparava a Igreja romana não floresciam ao sabor do acaso, pelo contrário, tinham que dar conta de numerosas instâncias da vida diária de coletividades inteiras. Aos eclesiásticos cabia suprir as demandas da Christianitas em sua totalidade, em toda sua cadência e constância ao longo dos tempos. Os encargos práticos da organização eclesial deviam tornar-se habituais e, submetidos a uma espécie de uma enorme rotina coletiva, vincular-se ao movimento estável dos meses e dos anos, ao giro eterno do calendário. A Santa Sé estipulava medidas supostamente capazes de garantir sua perduração, sua duração interminável. Uma busca pela conservação. Por consolidar-se. Perpetuar-se. Afinal, "se tornara permanente e permanentes eram suas emergências e necessidades", ${ }^{16}$ como confirma esta outra passagem das atas, na qual o cânone LXIV fez constar que "ordenamos aos bispos que publiquem este decreto anualmente em todas as igrejas". ${ }^{17}$ (grifo nosso).

Chegamos, assim, a um aspecto da maior relevância para a caracterização da representação do tempo contida nas atas do Lateranense IV: uma incontida ficção de continuidade, de uma infinidade prática que perpassava a apreciação romana de todo o corpo eclesiástico. Um atributo temporal de natureza profana, pois esta infinidade prática afirmava uma espécie de inesgotabilidade do mundo, enraizando a Igreja romana no material, no mundano, neste tempo cíclioco e corriqueiro que é o tempo da duração e das estações. Os eclesiásticos distanciavam-se, implícita e momentaneamente, de um postulado fundamental ao homo religiosus: a premissa, tão cara à patrísica latina, de que a finitude do universo e dos seres visíveis os coloca como inferiores ao metafísico, este sim a plenitude do ser, o realmente existente, posto que infinito e absoluto. ${ }^{18}$

Para a cúpula da Igreja romana, governar homens era obra sem fim. Não poderia haver interrupção, nem vazio possível. A atuação da

16 KANTOROWICZ, Ernst. Os dois corpos do rei. São Paulo: Cia das Letras, 1998, p. 178.

17 Cânone LXIV. In: HEFELE-LECLERQ: tomo V, p. 1384.

18 BROWN, Peter. Corpo e sociedade. Rio de Janeiro: Zahar, 1990; COMTE-SPONVILLE, André. O ser-tempo. São Paulo: Martins Fontes, 2000; ELIADE, Mircea. O sagrado e o profano. São Paulo: Martins Fontes, 1992; SCHUBACK, Márcia Sá Cavalcante. Para ler os medievais. Petrópolis: Vozes, 2000. 
Ecclesia em meio a cristandade deveria ser assiduamente freqüente, e se um clérigo devia ser repreendido por suas hesitações morais ou por professar uma fé que titubeava diante das tentações materiais e do imoral, o cânone XVII ordenava que ele devia igualmente ser advertido ao ser negligente com esta necessidade de permanência, de recorrência inacabável, permitindo que intervalos inertes se infiltrassem neste trabalho sem tréguas que eram as tarefas eclesiásticas:

Deploramos vivamente que alguns clérigos menores, mas também certos prelados passem quase a metade da noite em festejos ostentosos e em conversações indecorosas [...]. Outros celebram a missa apenas quatro vezes ao ano... ${ }^{19}$ (grifo nosso).

\section{2. "OS HOMENS PERECEM, MAS NUNCA O QUE LHES GOVERNA..."}

Ao atribuir tamanha continuidade e solidez ao devir, esta temporalidade romana, prática, implícita e sinuosa, destoava abruptamente dos valores temporais que os clérigos ocidentais da passagem dos séculos XII e XIII professavam em seus tratados teológicos e morais, especialmente no tocante à maneira com que estes homens encaravam o problema da duração da existência humana. E neste ponto, devemos reconhecer, poucas figuras são tão emblemáticas quanto o próprio papa que capitaneou o IV Concílio de Latrão.

"Correspondiam ao gosto e à visão da época", ${ }^{20}$ formulações como as que aparecem no De Contemptus Mundi sive De Miseria Conditionis Humanae ("Sobre a Fuga do Mundo ou a Miséria da Condição Humana"), um tratado moral escrito entre 1194 e 1195 pelo cardeal que anos mais tarde seria eleito papa sob o nome de Inocêncio III: Lotário di Segni. Neste opúsculo o homem é visto como

19 Cânone XVII. In: HEFELE-LECLERQ: tomo V, p. 1347.

20 MACCARRONE, Michele. Innocent III. In: VILLER, Marcel et al. (Org.). Dictionnaire de Spiritualité. Paris: Beauchesne, 1971, v. 7, col. 1770. 
desprezível [...]: concebido no prurido das carnes, no fervor do desejo, no fedor da luxúria [...], é nascido para o trabalho, para a dor, para o medo: por isso é desgraçado, para a morte. ${ }^{21}$

O homem, habitado pelo pecado, surge como um ser assombrado pelo "cursus-ad-mortem" e o tempo aparece sob a dolorosa epígrafe de "a maneira das coisas mutáveis", isto é, a marca da instabilidade, da incapacidade de persistir. ${ }^{22}$ A marcha temporal é vista como a esteira de mudanças dramáticas que assolam a vida de cada homem. Como manifestação do "deixar-de-ser" que arrasta toda criatura para a morte, o tempo era percebido como uma aflita contagem regressiva: a vida humana era tida como inquietantemente curta, tão breve que desencorajava o homem a agir. Tudo o que um cristão poderiam almejar era evadir-se do tempo e buscar refugio na eternidade.

Todavia, estes significados temporais alardeados a plenos pulmões por Lotário di Segni, são diametralmente opostos aos que encontramos nas atas do concílio presidido por Inocêncio III em novembro de 1215. Como se nosso cardeal, ao se tornar o líder de um vasto maquinário de governo, tivesse sido seduzido pelo tempo. Eis o cânone XIV:

Quem, suspenso por este pecado [incontinência], tiver o atrevimento de celebrar os santos mistérios, não somente será privado dos benefícios que possuir, mas também, por esta dupla falta, será destituído perpetuamente. ${ }^{23}$

E ainda, no cânone XXI:

Determinamos que quem revelar o pecado confessado ante o tribunal da penitência, seja não somente destituído do ministério sacerdotal, mas também reduzido, perpetuamente, ao estado

21 LOTÁRIO DI SEGNI. De contemptus mundi sive de miseria conditionis humanae. In: PL: v. 217, livro I, cap. I, col. 0702C.

22 LOTÁRIO DI SEGNI. De contemptus mundi sive de miseria conditionis humanae. In: PL: v. 217, livro I, cap. XII, col. 0707A.

23 Cânone XIV. In: HEFELE-LECLERQ: tomo V, p. 1345. 
de penitência em um mosteiro da mais severa observância. ${ }^{24}$ (grifo nosso).

"Perpetuamente". O emprego deste termo não passava de um uso corriqueiro da linguagem escrita de então? Uma utilização imediata, superficial e fortuita? Uma "maneira de dizer" óbvia e pouco significativa? Não aos nossos olhos. Nestes fragmentos, encaramos a palavra "perpetuamente" como a marca deixada por conteúdos implícitos mobilizados pelos sujeitos históricos no contexto em que produziam os cânones lateranenses. ${ }^{25}$ Conteúdos que, retomando o tema da infinidade prática, vêm realçar ainda mais o contraste entre a representação do tempo que permeia as práticas de governo da Santa Sé e aquela mobilizada conscientemente pela maioria dos clérigos dos séculos XII e XIII, incluindo-se membros do papado. Vejamos.

Não são escassas as afirmações de que os homens medievais, e dentre eles especialmente os eclesiásticos, eram absorvidos por uma aguda percepção da limitação cronológica que pesava sobre a vida humana, como se a seus olhos o ingresso na eternidade estivesse sempre a dois passos. Esta arguta consciência de finitude pode ser diagnosticada pela constância com que estes homens concebiam a existência humana como refém de uma tristeza do finito. ${ }^{26}$ Nas esculturas tumulares, apadrinhadas pelos religiosos medievais, encontramos uma valiosa expressão desta tristeza: os traços do envelhecimento, o corpo esquelético e enrijecido, o rosto brando e descarnado, as mãos enclavinhadas, os membros hirtos... ${ }^{27} \mathrm{~A}$ estatuária dava forma à usura cobrada pelo tempo junto à carne humana.

$\mathrm{Na}$ viragem do século XII ao XIII os clérigos medievais, emblematizados em Lotário di Segni, retornavam à matriz filosófica

24 Cânone XXI. In: HEFELE-LECLERQ: tomo V, p. 1351.

25 PÊCHEUX, Michel. Semântica e discurso. Campinas: EdUnicamp, 1988.

26 BLOCH, Marc. A sociedade feudal. Lisboa: Edições 70, 1983, p.102-103; BRAET, Herman; VERBEKE, Werner (Ed.). A morte na Idade Média. São Paulo: Edusp, 1996; DELUMEAU, Jean. História do medo no Ocidente. São Paulo: Cia das Letras, 1989; LE GOFF, Jacques. Na Idade Média: tempo da Igreja e o tempo do mercador. In: Para um novo conceito de Idade Média. Lisboa: Editorial Estampa, 1995, p. 43-60; (Dir.). O homem medieval. Lisboa: Presença, 1989, p. 26; VAUCHEZ, André. A espiritualidade na Idade Média Ocidental. Rio de Janeiro: Zahar Editor, 1995.

27 FOCILLON, Henri. Arte do Ocidente: a idade média românica e gótica. Lisboa: Estampa, 1993, p. 261-264; HUIZINGA, Johan. O declínio da Idade Média. São Paulo: Verbo: EDUSP, 1978, p. 129139. 
agostiniana ao definirem o homem como território de atuação do nada, do não-ser, e assim reforçavam o sentido trágico da existência de um ser "concebido em culpa, nascido para a punição, [...] comida de vermes, massa putrefata". ${ }^{28}$ Imerso no temporal, o homem e tudo que o envolvia eram vistos como precários, já que transitórios. Da concepção do homem acometido por uma existência perecível, surge uma imagem do tempo como algo que limitava inapelavelmente o alcance da vontade humana a duração de uma breve vida. ${ }^{29}$

O tempo individual era encarado como pouco favorável ao agir humano que se propõe duradouro, pois "quem há pouco sentava vaidoso no trono, em breve estará estendido desprezível no túmulo"..$^{30}$ Este mesmo período foi o contexto histórico da afirmação teológica do Purgatório, acrescentando novo alento a esta "sensibilização para o instante do trepasse". ${ }^{31}$ O nascimento desta terceira dimensão do Além cristão permitiu que os mortos deixassem de ser anônimos e coletivos para assumirem uma identidade individual e testamentária: um conforto diante do crescimento geral da preocupação com o desaparecimento individual. ${ }^{32}$ De acordo com P. Ariès, situamo-nos no século da clericalização da morte, ${ }^{33}$ época em que os eclesiásticos estavam constantemente às voltas como os temas agostinianos da finitude do mundo físico e da indigência ontológica das criaturas: ${ }^{34}$

O tempo gasta e a morte se aproxima. [...] A vida escapa rapidamente e não se pode retê-la, a morte ocorre instantaneamente e não se pode impedi-la, por isso aquela é extraordinária,

28 LOTÁRIO DI SEGNI. De contemptus mundi sive de miseria conditionis humanae. In: PL: v. 217, livro I, cap. I, col. 0702C.

29 GILSON, Étienne. Introduction a l'Étude de Saint Augustin. Paris: J. Vrin, 1969, p. $217-$ 255. PEGUEROLES, Juan. El pensamiento filosófico San Agustín. Barcelona: Labor, 1972, p. 67-77.

30 LOTÁRIO DI SEGNI. De contemptus mundi sive de miseria conditionis humanae. In: PL: v. 217, livro III, cap. I, col. 0735D.

31 LE GOFF, Jacques. O nascimento do purgatório. Lisboa: Estampa, 1995, p. 273.

32 LAUWERS, Michel. Morte e mortos. In: LE GOFF, Jacques; SCHMITT, Jean-Claude (Org.). Dicionário Temático do Ocidente Medieval. São Paulo: Imprensa Nacional, Bauru: EDUSC, 2002, v. 2, p. 243-259.

33 ARIÈS, Philippe. L'homme devant la mort. Paris: Seuil, 1977, p. 141-200.

34 GILSON, Étienne. A Filosofia na Idade Média. São Paulo: Martins Fontes, 1994, p. 721 734; LÉRTORA MENDONZA, Celina. O tema do infinito na Idade Média. Signum. São Paulo, n. 1, p. $145-$ $163,1999$. 
pois quanto mais cresce, tanto mais diminui, pois quanto mais a vida avança, tanto mais se dirige para o fim. ${ }^{35}$

O contexto histórico faz com que as palavras tenham pesos, e pesos distintos. Além de tudo que foi exposto acima, o rápido sucesso alcançado pelo De Contemptu Mundi nos círculos sacerdotais de sua época e a determinação papal que proibia, em Paris, o ensino das obras aristotélicas que afirmavam a eternidade do mundo, ${ }^{36}$ podem ser considerados sintomáticos de que nos meios eclesiásticos contemporâneos ao IV Concílio de Latrão alguns vocábulos possuíam um sentido marcante quando empregados para qualificar a condição humana. Eram mensageiros de um sentido tão crucial que poderiam ser o estopim de violentos debates doutrinários e até mesmo de condenações por heresia. No discurso religioso então aceito pela Igreja romana, a utilização de alguns termos dificilmente passaria despercebida por um clérigo: mortalis, finitus, aeternus, breves vitae, e... perpetuo. A esta constatação podemos acrescentar outra de grande relevância: uma vez restituída a este mesmo discurso clerical sobre os destinos humanos, a palavra perpetuo aparece atrelada ao sentido de "perene", de "contínuo", de "para sempre", um qualificador então utilizado para o sobrenatural, a natureza do espiritual, não para o terreno.

Como, então, entender a presença deste adjetivo nas atas de 1215 ? Porquê as condenações estipuladas nestes cânones parecem não levar em conta a finitude da vida humana ou mesmo contradizê-la tão abertamente? Uma indagação legítima, já que o papado assim o fez em outro concílio ecumênico de Latrão, em 1139: “Que estes (os usurários) sejam tidos por

35 LOTÁRIO DI SEGNI. De Contemptus Mundi sive De Miseria Conditionis Humanae. In: PL: v. 217, livro I, cap. XXIV, col. 0713D-0714A. Este trecho extraído do opúculo de Lotário di Segni exibe uma notável semelhança com as reflexões agostinianas sobre a vida e seu signifcado temporal: "Pois desde o instante em que começamos a existir neste corpo mortal, jamais deixamos de tender para a morte [...]. Não existe ninguém que não esteja mais próximo da morte depois de um ano que antes dele, amanhã mais do que hoje, hoje mais do que ontem [...], de tal modo que esta vida não passa de corrida para a morte". (AGOSTINHO DE HIPONA. Cidade de Deus. Petrópolis: Vozes, 2001, p. 100-104).

36 Em agosto de 1215, o cardeal Robert de Courçon, legado de Inocêncio III encarregado da convocação para o IV concílio de Latrão no reino da França, outorgou aos mestres e estudantes de Paris uma carta que, em nome do papa, estipulava pontos para a organização e funcionamento das escolas. Neste documento foi proibido o ensino da Metafísica e da Filosofia Natural de Aristóteles. In: ULLMANN, Reinholdo Aloysio. A universidade medieval. Porto Alegre: Edipucrs, 2000, p. 164-165. 
infames durante toda sua vida e se não chegam a ememdar-se, sejam privados de sepultura eclesiástica", ${ }^{37}$ ou ainda, que "estes [os usurários] sejam tidos por infames durante toda sua vida". ${ }^{38}$ Note-se bem: "por toda sua vida" e não "perpetuamente"... Como explicar que homens tão sensíveis às limitações impostas pelo tempo à natureza humana tenham decretado a um prelado delituoso a sentença de um despojamento perpétuo? Perpetuidade e finitude humana não são incompatíveis? Sobretudo sob a ótica religiosa medieval de então?

Esses questionamentos tornam-se ainda mais intrigantes ao constatarmos que as punições acima transcritas nada tinham de espiritual, como uma sentença a ser consumada no Além, como uma excomunhão ou uma danação eterna, veredicto decretado pela própria Santa Sé na legislação conciliar de 1139:

Quem os tem recebido [os dízimos] dos bispos, dos reis ou qualquer outra pessoa, sem não os restituir à Igreja, saibam que cometem o pecado de sacrilégio e que correm perigo de condenação eterna [aeternae damnationis]. ${ }^{39}$ (grifo nosso).

Temos de "ouvir, naquilo que o sujeito diz, aquilo que ele não diz, mas que constitui igualmente os sentidos de suas palavras". ${ }^{40}$ Isto é, que esta especificidade lexical das atas de 1215 deve-se ao fato de veicularem uma advertência: a temporalidade dos indivíduos (o tempo vivido por cada um) não se mistura à temporalidade do corpo eclesial (o tempo de uma organização coletiva estruturada).

No Lateranense IV não nos deparamos apenas com uma síntese, mas igualmente com a imposição de uma representação temporal. Imposição que parece ter acometido o próprio papa, outrora tão obcecado pela precariedade das ações humanas. Os parâmetros temporais de uma Igreja em franco processo de concentração de poderes eram aqueles construídos pela e para a coletividade, esmagando os valores atribuídos ao tempo tal

37 Cânone XIII do Lateranense II. In: Mansi: v. XXI, col. 0530A.

38 Id.

39 Cânone X do Lateranense II. In: MANSI: v. XXI, col. 0528E.

40 ORLANDI, Eni. Análise de discurso. Campinas: Pontes, 1997, p. 59. 
como vivido individualmente. Significados corporativos, como o de continuidade e perpetuidade, assumiam o primeiro plano da qualificação temporal, sobrepondo-se àqueles existenciais, como a transitoriedade e finitude. Afinal, os referidos cânones não estenderam a punição até o fim da vida do faltoso, ou seja, até a sua morte, mas perpetuamente.

A normalidade com que o vocábulo perpetuo aparece nas constituições de 1215 para caracterizar um estado humano sugere-nos que sua utilização era guiada por outro valor temporal que não o existencial: perpetuo aqui não se refere, em última instância, ao indivíduo, mais à própria Igreja romana. Pois, ao contrário do indivíduo, que era concebido como mutável e, desta forma, morria um pouco a cada instante em direção a um fim inevitável, o papado das atas do IV Concílio de Latrão expressava, de maneira oblíqua, a convicção em sua continuidade, em sua estabilidade, em sua infinitude prática. Assim, suas medidas - bem como os resultados a serem por elas obtidos - foram estipuladas sem término previsto, como um trabalho sempre inacabado...

Querendo desterrar de uma vez por todas este mal [promover pessoas indignas a benefícios eclesiásticos], decretamos que se destitua aos indignos e, em seu lugar sejam concedidos esses cargos a pessoas aptas, desejosas e capazes, ao mesmo tempo, de render e prestar um serviço agradável a Deus e à Igreja. Nesta matéria que nos ocupa, por causa da celebração do concílio provincial, far-se-á todos os anos uma investigação séria e a fundo. ${ }^{41}$ (grifos nossos).

O giro constante do calendário ("far-se-á todos os anos uma investigação...") podia oferecer à Cúria romana garantias de que um delito não mais ocorreria, pois a correção deveria vigorar interminavelmente (" $d e$ uma vez por todas...").

Policiava-se o delito mais do que o faltoso. Não era o clérigo o verdadeiro alvo das atenções da punição, mas a preservação da eficácia das normas canônicas, ou seja, a salvaguarda da idoneidade da Igreja romana. Era indubitavelmente o prelado que sofria a pena, nele cumpria-se a medi- 
da corretiva, mas os efeitos da repreensão deveriam se fazer sentir na totalidade da malha eclesiástica, isto é, na manutenção da integridade do corpus eclesial romano. Pois, ao contrário do sacerdote, que irremediavelmente passaria e morreria, a hierarquia encabeçada pela Santa Sé sobreviveria, persistiria em meio a homens que ainda nasceriam, continuaria a agir nos tempos futuros. O que explica esta necessidade de que as faltas fossem não apenas combatidas, mas extintas; e não apenas durante o período de vida do faltoso, mas "perpetuamente", "de uma vez por todas"...

O léxico temporal encontrado nos cânones indica-nos que os reformadores romanos de 1215 subentendiam o corpo eclesial como poupado de qualquer limitação temporal. Mas este vocabulário é aqui um conjunto de qualificações não propositais, uma série de valores temporais não confessados pelos agentes históricos, mas que sustentavam as medidas por eles decretadas. Os vocábulos utilizados não meramente descrevem ou exteriorizam uma concepção de tempo, eles a constroem à revelia da lucidez daqueles que a mobilizam, e o faziam no interior deste processo em que falar algo é já criar, é constituir aquilo de que se fala, quando se fala. ${ }^{42}$ Este vocabulário sugere-nos que os padres conciliares não concebiam a Igreja como eterna, mas postulavam regras para o agir pautadas numa implícita recorrência infindável. Desta forma as ações ditadas pelo papado eram naturalizadas como perpétuas, assumindo a aparência de um dado: a formulação de sua inesgotabilidade ocorrera de maneira por demais óbvia e natural para serem notadas como uma imposição ou uma construção cultural. A existência da Igreja romna era marcada por uma infinidade prática, não uma consciência de eternidade.

Com esta representação do tempo, o todo se sobrepunha às partes. Já que na ocorrência de uma falta era a Igreja romana que era lesada, o que exigia uma reparação junto ao indivíduo. O infrator era obrigado a compensar a ordem e os princípios deste corpo coletivo organizado contra os quais ele atentou. Por isso ele devia sofrer "perpetuamente" os efeitos de uma punição, por isso ele se submetia a infinidade prática postulada pela Santa Sé: era a restituição devida a um valor temporal lesado, a saber, a permanência da estrutura eclesial romana. O clérigo devia existir para a Igreja antes da Igreja existir através dele. Este tempo coletivo caminhava a 
passos largos para uma espécie de impessoalidade, de indiferença ao existencial. O cânone LXIV é excepcional quanto à forma com que a Santa Sé impunha-se tanto aos fiéis como aos clérigos e como esta imposição alcançava tons austeros e implacáveis...

Em nosso desejo de pôr limites a este vício [simonia] e extirpálo inteiramente, decretamos que: toda pessoa que no futuro se faça culpada desta falta, tanto a que recebe como a que é recebida - seja simples monja ou pessoa que ostenta um cargo - será expulsa de seu mosteiro sem esperança de reintegrar-se ao mesmo e recolhida em uma casa de estrita observância para que faça nela penitência, perpetuamente. ${ }^{43}$ (grifo nosso).

Trecho por demais severo este em que a sede de perpetuar-se se impunha até mesmo à possibilidade de um faltoso em ter esperança. Calcando suas ações sobre o postulado de uma infinidade prática da duração, o papado fundava sua organização na cadência temporal ordinária, cotidiana e contínua, tornando natural e absoluta sua própria existência. Assim, os legisladores romanos de 1215 afirmavam um valor positivo ao tempo terreno sem apelar ao transcendente, sem recorrer aos mistérios de um tempo sagrado e metafísico. Esta qualificação profana do tempo pela Santa Sé era tão marcante que tentava a emudecer este freqüente porta-voz do sagrado que é a esperança alheia.

\section{Epílogo}

Na obra legislativa produzida pelo IV Concílio de Latrão não encontramos o tradicional "tempo da Igreja" do qual J. Le Goff tornou-se o maior divulgador ${ }^{44} \mathrm{~A}$ fisionomia aí assumida pelo tempo não corresponde àquela de badalas de sinos monásticos em meios aos campos, da duração

43 Cânone LXIV. In: HEFELE-LECLERQ: tomo V, p. 1384.

44 LE GOFF, Jacques. Na Idade Média: tempo da Igreja e... op. cit., p. 43-60; A civilização do ocidente medieval. Lisboa: Estampa, 1995, v. 2, p. 93-100. 
das penas nos manuais penitenciais ou do sacramental ritmo cíclico do calendário religioso. Ele não assume as vertiginosas feições de um tempo histórico impregnado de sagrado, de um devir de contornos cósmicos e místicos, de ressonâncias sobrenaturais, como a linear sucessão temporal desencadeada no ato da Criação e que transcorre para o Apocalipse. ${ }^{45}$ Não se trata de um tempo teológico, dos destinos celestiais, dos ofícios litúrgicos ou dos assuntos da alma.

Esta imago temporalis registrada em 1215 em nada lembra-nos a subjetividade da distentio anima de Agostinho de Hipona, ${ }^{46}$ as horas canônicas consagradas aos ofícios monásticos pela Regula de Bento de Núrsia, ${ }^{47}$ o constante trânsito de espíritos entre planos temporais descrito na Legenda Áurea de Jacopo de Varezze ${ }^{48}$ ou a vertiginosa marcha bíblica da história que, na Chronica de Otto de Freising ou no Speculum Historiale de Vicent de Beauvais, deságua de Adão ao Juízo Final. ${ }^{49}$ Estamos diante de uma temporalidade, por assim dizer, mais "sóbria", colocada ao "rés-dochão" dos encargos de comando, isto é, criada para propiciar uma gestão institucional pragmática e destinada a se auto-perpetuar. Aqui, o tempo se presta a uma utilização estritamente racional, impessoal e previsível. Se tomarmos de empréstimo as palavras de Joseph Strayer, podemos afirmar que explorar esta singular temporalidade romana equivale a examinar "um sinal [...] da possível emergência de um estado: a formação de instituições políticas impessoais e relativamente permanentes". ${ }^{50}$

45 BARBER, Malcolm. The two cities: medieval Europe 1050-1320. Nova York: Routledge, 1992. p. 391-398; CARMONA FERNÁNDEZ, Fernando. La mentalidad literaria medieval. Murcia: Universidad de Murcia, 2003, p. 41-51; FAURE, Raphaël; NADAL, Franck (Orgs). De l'histoire aux légendes du temps médiéval. Centre de Développement en Art et Culture Médiévale. Disponível em: <http:// cdacm.free.fr/>; GUREVITCH, Aron. As categorias da cultura medieval. Lisboa: Caminho, 1990, p. 115172; MARTIN, Hervé. Mentalités Médiévales. Paris: PUF, 1996, p. 155-174; NISBET, Robert. Historia de la idea de progreso. Madrid: Gedisa, 1988; PATTARO, Germano. A concepção cristã do tempo. In: UNESCO (Org.). As culturas e o tempo. Petrópolis: Vozes, 1975, p. 197-228; SCHMITT, Jean-Claude. Le corps, les rites, les rêves, le temps. Paris: Gallimard, 2001.

46 AGOSTINHO DE HIPONA. Confissões. São Paulo: Abril S/A., 1974.

47 LA REGLA DE SAN BENITO. Madrid: Editorial Católica, 1979 (B.A.C., v. 406).

48 JACOPO DE VAREZZE. Legenda áurea. São Paulo: Cia das Letras, 2003.

49 ARIÉS, Philippe. O tempo da história. Lisboa: Relógio d’Agua, 1992; GILSON, Étienne. A filosofia na Idade Média. São Paulo: Martins Fontes, 1994; L'esprit de la philosophie médievale. Paris: J. Vrin, 1936, p. 183-198; GUENÉE, Bernard. Histoire et culture historique dans l'Occident médiéval. Paris: Aubier, 1980, p. 18-38; LÖWITH, Karl. O sentido da história. Lisboa: Edições 70, 1991.

50 STRAYER, Joseph. As origens medievais do estado moderno. Lisboa: Gradiva, [19-?], p. 12. 
Governar exigia pelejar com o tempo. Justamente o que obrigou o soturno cardeal Lotário de Segni a, uma vez entronizado como soberano do império pontifical, realizar um acerto de contas com o devir. Em meados dos anos 90 do século XII nos deparamos com um cardeal possivelmente postergado pelo pontífice de então em razão de rivalidades familiare ${ }^{51}$ que embevecia seu opúsculo de meditações sobre a natureza humana com a concepção de que medir o tempo, distribuí-lo em dias, meses ou anos, não passava de uma frivolidade, pois quer se tratasse de um dia ou de centenas de anos, pouco importava, são todos tempos passados, desaparecidos, inalcançáveis, mortos: "Mil anos estão mortos diante dos olhos da mesma maneira que o dia de ontem, que passou". ${ }^{52}$ Porém, apenas alguns anos mais tarde, conta-nos seu biógrafo que este mesmo homem, agora sumo pontífice, é incapaz de se desprender da sucessão cronológica, vive agarrado a porções de tempo, regendo sua administração seguindo o compasso preciso de uma periodicidade:

Três vezes por semana ele celebrava publicamente o solene consistório, que havia caído em desuso. Aí ele tratava de queixas individuais, as causas de menor importância instruía a outros. Reservava a si as mais importantes de uma maneira tão sutil e prudente que a todos deslumbrava... ${ }^{53}$

Esta nítida adesão de um importante membro do papado a uma nova temporalidade pode ser tomada como indício de que a aparelhagem institucional montada pelo papado medieval, entre 1050 e 1215, detém uma densidade cultural própria, genuína; uma maior robustez histórica do que aquela comumente reconhecida pela historiagrafia voltada para o papado medieval e que ao longo do século XX pareceu se dividir entre duas grandes vertentes.

O primeiro e mais antigo fronts - hegemônico na primeira metade do século XX, mas ainda influente na década de 1970 - foi aquele que abrigou a história institucional da Santa Sé, reunindo nomes como G.

51 Lotário pertencia aos Conti, então ferrenhos inimigos da linhagem dos Orsini, da qual provinha Giacinto Boboni, o octagenário Celestino III, pontífice que antecedeu a Inocêncio III de 1191 a 1198.

52 LOTÁRIO DI SEGNI. De contemptus mundi sive de miseria conditionis humanae. In: PL: v. 217, livro I, cap. XXIV, col. 0713D-0714A.

53 GESTA INNOCENTII PAPAE III. In: PL: v. 214, col. 0041. 
Barraclough e Bihlmeyer \& Tuchle,${ }^{54}$ historiadores empenhados em contemplar o papado em sua estruturação propriamente governamental. Eis uma literatura cuja marca distintiva é vislumbrar a Cúria romana em sua singularidade, realçando as especificidades dos processos que a distinguiam face aos demais ambientes da "Igreja Medieval": os autores dissecam a montagem dos departamentos que a compõem, empregam grande fôlego no exame da composição de seus quadros funcionais; no esmiuçar de sua rede tributária e legislativa... ${ }^{55}$ Todavia, logo se fez ouvir a crítica de que se estes estudiosos nos apresentam aspectos históricos que individualizaram o papado, eles por vezes deram vazão a uma perspectiva assaz descritiva, formal, porventura seca, por demais presa à simples exposição das engrenagens administrativas que moviam o papado ou às minúcias de sua justificação intelectual por papas e cardeais. Tais limitações teriam conduzido A. Fliche a restringir as atuações do papado sobre a sociedade medieval à condição de intervenções essencialmente moralizadoras catalisadas pela "luta das investiduras", ${ }^{56}$ perspectiva seguida de perto por Knowles \& Obolensky. ${ }^{57}$ Especialmente ilustrativas são ainda duas conhecidas obras de G. Le Bras $^{58}$ que parecem canalizar para a Cúria romana a carga positivista da sociologia de durkheiminina, diferentemente de seus estudos sobre o catolicismo francês..$^{59}$

Reconhecendo tais limitações, estudiosos ambientados nas décadas de 1970 a 1990, apelaram a olhares considerados mais penetrantes e abrangentes ${ }^{60}$ : alguns, como R. Moore, se inspiraram em um exame capaz

54 BARRACLOUGH, Geoffrey. Os papas na Idade Média. Lisboa: Verbo, 1972; BIHLMEYER, Karl; TUCHLE, Herman. Histoire de l'église. Paris: Salvator, 1964, tomos II e III.

55 GARCIA-VILLOSLADA, Ricardo. História de la iglesia católica: Edad Media (8001303). Madrid: Catolica, 1976; HUGUES, Philip. História da igreja católica. São Paulo: Editora Nacional, 1954; JACQUIN, A-M. Histoire de l'église. Paris: Brouwer, 1948, tomos III-IV; LEFEBVRE, Charles, LE BRAS, Gabriel; RAMBAUD, Jacqueline. L'Age Classique: sources et théorie de droit. Paris: Sirey, 1965; . Le gouvernement de l'église à l'époque classique. Paris: Sirey, 1965.

56 FLICHE, Agustín et al. La Cristiandad. op. cit.; . Reforma Gregoriana y Reconquista. Valência: Edicep, 1976.

57 KNOWLES, David; OBOLENSKY, Dimitri. Nova história da igreja. Petrópolis: Vozes, 1974.

58 LE BRAS, Gabriel. La Iglesia Medieval. Valencia: Edicep, 1976; Institutions ecclésistiques de la chrétienté médiévale. Paris: Bloud \& Gay, 1959.

59 LE BRAS, Gabriel. Études de sociologie religieuse. Paris: Presses Universitaires de France, 1955-1956; . Sociologie religieuse et droit canonique. L'Anné Canonique. Paris: Letouzey, 1952.

60 VAN ENGEN, John. The future of medieval church history. Church History. Yale, v. 71, n. 3, p. 492-522, 2002. 
de abarcar "la relación entre autoridad y sociedad"; ${ }^{61}$ ou, como fez R. Southern, de alertar que "the habit of separanting ecclesiastical history from secular history has tended to make everything ecclesiastical appear more rarefied than it really is", ${ }^{62}$ de apresentar, tal como I. Robinson, "the institutions of the papal government in action" " ${ }^{63}$ ou, aludindo ao olhar de B. Bolton, de vasculhar a reação do papado ao "grande fermento espiritual do século XII" ${ }^{64}$ Para outros historiadores, atuantes desde a década de 1950, como M. Pacaut ${ }^{65}$ e W. Ullmann, ${ }^{66}$ a história institucional da Santa Sé recobrou fôlego epistemológico no momento em que os historiadores perceberam que esta incrível sofisticação das técnicas pontifícias de governo era animada pela secular formulação de um ideário político cada vez mais pujante, ambicioso, audaz ao reivindicar ao papado a soberania sobre toda a Cristandade: o pensamento e o discurso políticos são assim convertidos em roda-de-proa das engrenagens institucionais, em seu centro gravitacional. ${ }^{67}$

13.

61 MOORE, Robert. La formación de una sociedad represora. Barcelona: Crítica, 1989, p.

62 SOUTHERN, Richard William. Western Society and The Church in the Middle Ages. Londres: Penguin Books, 1990, p. 360.

63 ROBINSON, Ian Stuart. The Papacy 1073-1198. Nova York: Cambridge University Press, 1996, p. vii-viii.

64 BOLTON, Brenda. A Reforma na Idade Média. Lisboa: Edições 70, 1983, p. 13; CONSTABLE. Giles. The Reformation of the Twelfth Century. Cambrigde: Cambrigde University Press, 1996. Poderiam ser incluídas nesta perspectiva: DU JORDIN, Michel Mollat et al. Un Temps d'Épreuves (1274-1449). Paris: Desclée-Fayard, 1998; JOHNSON, Paul. História do Cristianismo. Rio de Janeiro: Imago, 2001; MORRIS, Colin. The Western Church from 1050 to 1250. Londres: Clarendon Press, 1991; RAMOS, Luís Garcia-Guijarro. Papado, Cruzadas Y Ordenes Militares: siglos XI-XIII. Madri: Cátedra, 1995; TELLENBACH, Gerd. Church, State and Christian Society at the time of the Investiture Contest. Toronto: University of Toronto Press, 1991; ULLMANN, Walter. A Short History of the Papacy in the Middle Ages. 2. ed. Londres: Routledge, 2003; VAUCHEZ, André et al. Apogée de la Papauté et Expansion de la Chrétienté. Paris: Desclée-Fayard, 1998.

65 PACAUT, Marcel. La Théocratie: L’Eglise et le Pouvoir au Moyen Age. Paris: Aubier, 1957.

66 ULLMANN, Walter. Escritos sobre teoria política medieval. Buenos Aires: Editora Argentina, 2003; Medieval papalism: the political theories of the medieval canonists. Londres: Methuen, 1949.

67 ARQUILIÈRE, Henri-Xavier. L'Augustinisme Politique. Paris: J. Vrin, 1955; BURNS, James Henderson (Dir.). Histoire de La Pensée Politique Médiévale. Paris: PUF, 1993; CONGAR, Yves. L'Église: de Saint Augustin à 1'Époque Moderne. Paris: du Cerf, 1970; Papado e Igreja. São Paulo: Loyola, 1997; DUFFY, Eamon. Santos e pecadores. São Paulo, Cosac \& Naify, 1998; GIERKE, Otto Friedrich von. Political Theories of the Middle Age. Cambridge: Cambridge University Press, 1987; SOUZA, José Antônio; BARBOSA, João Morais. O Reino de Deus e o Reino dos Homens. Porto Alegre: Edipucrs, 1997. 
No outro flanco historiográfico situaríamos nomes filiados à história cultural que, como J. Le Goff, fornecem um influente enquadramento histórico para o papado medieval, ainda que este propósito não constitua o cerne de suas pesquisas. ${ }^{68}$ Trata-se de historiadores que, guiados por uma apreciação antropológica, seguem as pistas de mentalidades, imaginários e sensibilidades coletivas. Aqui o papado é perdido de vista: ele parece liquefazer-se numa imensa população clerical que compunha a "Igreja em tempos medievais", como quiseram H. Martin e J. Paul. ${ }^{69}$ Suas singularidades são dissolvidas no momento em que seus integrantes são recrutados, como fez A. Gurevitch, para atestar a "personalidade do homem medieval", ${ }^{70}$ para ilustrar, como operou J. Delumeau, crenças coletivas sobre o pecado ${ }^{71}$ ou para restituir, como propôs $\mathrm{P}$. Ariès, as representações vigentes acerca da morte. $^{72}$

Este olhar vê muito pouco de um conteúdo próprio às malhas institucionais do papado: ele as vislumbra como um palco em que os protagonistas são alterações culturais, ao mirá-las ele não busca se não o rastro das mentalités, o traçado de bens simbólicos que permeiam toda uma sociedade. Porém, se estas obras incorrem num ímpeto homogeneizador e globalizante, elas detém o mérito de reconhecer a opacidade que encerra as transformações históricas e que, portanto, se deve, muitas vezes, superar o que os homens reconhecem sobre si mesmos para alcançar a complexidade das ramificações culturais que os envolvem e que projetam um poder performático sobre suas ações.

$\mathrm{Na}$ primeira perspectiva os sujeitos históricos são propriamente indivíduos; idéias e discursos; círculos, trajetórias e escalonamentos sociais. O faro do historiador, o guia para a racionalidade do agente histórico ou para a atuação constitutiva de sua linguagem política na montagem, no funcionamento e na legitimação do aparato de governo movido pelo papado;

68 LE GOFF, Jacques. A percepção do espaço da cristandade pela cúria romana e a organização de um concílio ecumênico em 1274. In: 101-108; O nascimento do... op. cit. O imaginário medieval. Lisboa: Estampa, 1994, p.

69 MARTIN, Hervé. op. cit.; PAUL, Jacques. La Iglesia y la Cultura en Occidente (siglos IX-XII). Barcelona: Labor, 1988, 2.v.

70 GUREVITCH, Aron. As categorias da... op. cit.

71 DELUMEAU, Jean. O pecado e o medo. São Paulo: UNESP, 2003, v. 1.

72 ARIÈS, Philippe. L homme devant la mort. Paris: Seuil, 1977, p. 141-200. 
perseguem-se suas ações repressoras e as forças motrizes de seus instrumentos de dominação. Já na segunda, os protagonistas são antes as "atitudes mentais": suas profundezas sociais e holísticas, e seu papel na estruturação de relações de poder e controle social. A Cúria romana é engolida por um mar de processos históricos cuja magnitude societária arrebata-a, convertendo seus integrantes em partes de um austero e coletivo homo simbolicus que se revela pela dilatada - e por vezes imprecisa estatura de uma "mentalidade clerical" ou uma "sensibilidade eclesiástica". Em ambos horizontes, as ocorrências propriamente institucionais, aspectos centrais da perspectiva histórica do combatido fantasma "positivista", ${ }^{73}$ parecem não merecer atenção em si mesmas, sendo exibidas como viés de realização de outros processos e instâncias históricas.

Poderia se alegar que, se levarmos em consideração um quadro historiográfico mais amplo, constataríamos que a história política - esteira da história institucional - há muito se tornou alvo de uma nítida renovação epistemológica que implica em sorver recortes temáticos, conceitos e metodologias das ciências sociais em geral. Tendência que conta com a contribuição dos medievalistas - cujos esforços fazem ressoar o pioneiro legado de M. Bloch ${ }^{74}$-, ainda que estes não tenham por objeto de estudos a Santa Sé ou mesmo a "Igreja Medieval". Desta forma, a História Política foi convertida em História do Poder Político, de "maior centro e profundidade". ${ }^{75}$

Todavia, quando os estudiosos alargaram os reinos da política em direção às pressões sociais, à sua cadência cotidiana e à sua "teatralidade" de um longo cortejo de imagens, símbolos, rituais, crenças e comportamentos, a face propriamente institucional do político parece ter sido, de manei-

73 BOURDÉ, Guy; MARTIN, Hervé. As escolas históricas. Lisboa: Europa-América, 1990, p. 97-108. BOUTIER, Jean; JULIA, Dominique (Org.). Passados recompostos. Rio de Janeiro: FGV, 1998, p. 22-31.

74 BLOCH, Marc. Os reis taumaturgos. São Paulo: Cia das Letras, 1993. Ver ainda: Apologia da História. Rio de Janeiro: Zahar Editor, 2001.

75 LE GOFF, Jacques. A Política será ainda a ossatura da História? In: O maravilhoso e o quotidiano do ocidente medieval. Lisboa: Edições 70, 1990, p. 215-235. Ver ainda: FALCON, Francisco. História e Poder. In: CARDOSO, Ciro F.; VAINFAS, Ronaldo. Domínios da História. Rio de Janeiro: Campus, 1997, p. 61-81. 
ra ainda mais enfática, deslocada do foco historiográfico.$^{76}$ Afinal, o historiador que se detém no institucional é encarado como aquele que se contenta com a face meramente "visível do político", que deixa escapar a intricada e microscópica malha de poderes locais e disciplinares que trespassam a sociedade. ${ }^{77}$ Este é o estudioso que expõem a si mesmo ao risco de um encastelamento, de negligenciar as ligações que conectam o político "por mil vínculos, por toda espécie de laços, a todos os outros aspectos da vida coletiva". ${ }^{78}$

Os componentes institucionais de um aparato de governo são considerados auxiliares, secundários, como instrumentos de ação desprovidos de conteúdo próprio, formas de organização destinadas a satisfazer as necessidades de outros domínios da vida humana: utensiliagem elaborada para operar a realização de algum poder ou princípio que lhe são exteriores. ${ }^{79}$ São as engrenagens que põem em movimento as pressões sociais, as diretrizes do ideário político ou da "mentalidade" e, para o historiador, seu estudo deve ser precedido pelo exame das "exigências de espírito" que lhes conferem vitalidade. ${ }^{80}$

O fenômeno da institucionalização do papado na Idade Média não pode ficar restrito à suas facetas propriamente burocráticas, jurídicas ou de um ideário político: há outras dimensões do institucional, incomparavelmente mais vastas que a administrativa, que podem brusca ou veladamente entrar em jogo quando o agente histórico persegue suas "ambições políticas". A originalidade institucional do papado medieval, ou seja, sua capacidade de compor respostas às necessidades de otimização das relações de

76 BALANDIER, Georges. Antropologia política. Lisboa: Presença, 1980; Opoder em cena. Brasília: EdUNB, 1982; BURKE, Peter. A fabricação do rei. Rio de Janeiro: Zahar, 1994; DUBY, Georges. A Idade Média na França. Rio de Janeiro: Zahar, 1992 ; . As três ordens ou o imaginário feudal. Lisboa: Estampa, 1994; FRANCO JR., Hilário. Adoce França. In: MONGELLI, Lênia Márcia (Coord.). Mudanças e rumos: o ocidente medieval (séculos XI-XIII). Cotia: Íbis, 1997, p. 53-81; SILVA, Marcelo Cândido. O poder na Idade Média entre a História Política e a Antropologia Histórica. Signum. São Paulo, n. 5, p. 233-252, 2003.

77 FOUCAULT, Michel. Microfísica do poder. Rio de Janeiro: Graal, 2002.

78 RÉMOND, René (Org.). Por uma história política. 2. ed. Rio de Janeiro: FGV, 2003, p. 35.

79 BOBBIO, Norberto. Estado, governo, sociedade. Rio de Janeiro: Paz e Terra, 2004; STRAYER, Joseph. As origens medievais do Estado moderno. Lisboa: Gradiva, 1989.

80 GUENÉE, Bernard. O Ocidente nos séculos XIV e XV: os estados. São Paulo: EdUSP, 1981. 
poder em que está imbricado, ultrapassa a criação de tributos, de procedimentos cada vez mais especializados ou de princípios de governo cada vez mais cobiçosos. Ela comportar em si elaborações históricas mais astutas, sutis e de maior magnitude, isto é, uma organização genuinamente institucional dos sentidos de agir, das motivações lógico-significativas das práticas.

A institucionalização do papado entre ao século XI ao XIII implicou na elaboração de uma disposição cultural própria: códigos de sentido, tramas simbólicas plenas de coordenadas de ação através das quais o poder pontifício regulamentara comportamentos, orientara condutas, operara novas relações de poder... Tal como uma singular temporalidade. Além de suas usuais feições de político, intelectual e administrativo, o institucional é também cultural.

Portanto, esta peculiar imago temporalis não pode ser contemplada como "idioma", "semântica" ou "cimento" do institucional, mas como uma de suas principais formas de estruturação. Nas palavras de G Pronovost: "as instituições produzem o tempo, no sentido de que elas obrigam os atores sociais a inscrever suas atividades em quadros temporais determinados em função da orientação que lhes são próprias". ${ }^{81}$

Estes usos não previstos do decurso temporal e constituem uma estratégia do papado para adaptar-se ao inquieto Ocidente do século XII, uma criação institucional de grande quilate histórico que fez com que a Igreja romana - por mais ambíguo e paradoxal que isso possa soar - tomasse parte efetiva desta modificação lenta e decisiva e cujos impactos talvez nunca se possa precisar com segurança nos rumos da civilização ocidental: a secularização do tempo.

81 PRONOVOST, Gilles. Temps sociaux et temps scolaire en Occident. In: ST-JARRE, Carole; DUPUY-WALKER, Louise (Dir.). Regards multiples sur le temps. Sainte-Foy: PUQ, 2001, p. 47. 